\title{
An ethnic ethnographic review: The kinship system of the Dayak Ribun tribe in West Kalimantan
}

\author{
Arkanudin $^{1 *}$, Rupita1 ${ }^{1}$ Ignasia Debbye Batuallo \\ ${ }^{1}$ Faculty of Social and Political Sciences, Tanjungpura University, Indonesia. \\ *Correspondance author: arkanudin@fisip.untan.ac.id
}

\begin{tabular}{|c|c|}
\hline ARTICLE INFO & ABSTRACT \\
\hline $\begin{array}{l}\text { Keywords: } \\
\text { Kinship System; Dayak } \\
\text { Ribun; Ethnic; } \\
\text { Ethnography. } \\
\text { How to cite: } \\
\text { Arkanudin., Rupita., } \\
\text { Batuallo, I.D. (2021). An } \\
\text { ethnic ethnographic } \\
\text { review: The kinship system } \\
\text { of the Dayak Ribun tribe } \\
\text { in West Kalimantan. } \\
\text { ETNOSIA: Jurnal } \\
\text { Etnografi Indonesia. 6(2), } \\
\text { 241 - 251. } \\
\text { DOI: } \\
\text { 10.31947/etnosia.v6i2.18098 }\end{array}$ & $\begin{array}{l}\text { This research aims to explore the kinship system of the Dayak Ribun } \\
\text { tribe in West Kalimantan. It uses the kinship system tree to visualize } \\
\text { the relationship roots. This effort is also based on the refinement of the } \\
\text { tree that has existed in the past. Moreover, the method used is an } \\
\text { ethnographic approach, where data collection is carried out explicitly } \\
\text { using observation, in-depth interviews, and live-in. Ethnic } \\
\text { ethnography is gathering a variety of information from its source. } \\
\text { According to the results, the kinship system in the Dayak Ribun } \\
\text { community is bilateral, that is, relations through two family lineages, } \\
\text { both sides of the mother or wife and father or husband. The principle } \\
\text { of heredity is bilateral, where the responsibilities of husband and wife } \\
\text { are the same in the family, both in children's education and in } \\
\text { controlling the family economy. The marriage of a family member who } \\
\text { is still a descendant from both the father and the mother is strictly } \\
\text { prohibited, which is only allowed to marry between cousins three } \\
\text { times. In the distribution of inheritance, there is no difference between } \\
\text { sons and daughters. Still, there are differences in some instances, } \\
\text { especially for those who remain with their parents. They will get a } \\
\text { higher share because they are responsible for their parents' old age } \\
\text { until they die. }\end{array}$ \\
\hline
\end{tabular}

\section{Introduction}

The Dayak Ribun tribe inhabits the Kalimantan Island and consists of hundreds of ethnolinguistic groups. This diverse class is categorized into large Dayak tribes because of their similarities in cultural elements such as physical form, the settlement of longhouses, linguistics, and the corpus of oral traditions. In addition, they hold customs, social structures, forms of weapons, and views on the universe in common (King, 1978; Kedit, 1988; Zulkarnaen, 2000). The Dayak people name their children according to the tribe or sub-tribe title, such as the orang Kenyah, orang Kayan, orang Bahau, orang Tunjung and others (Coomans, 1987). They are also dispersed throughout Kalimantan, in small communities with different linguistic accents, traditions, as well as customs, and have a unitary customary area called the benua (Mudiyono, 1993; Situmeang et al, 2020). 
The Dayak Ribun tribe in Kalimantan consists of 405 sub-tribes (Lontaan, 1975). However, the existence of these is difficult to distinguish because there is no accurate data on the differences in their characteristics (Aflanie et al, 2020). Some identify their distinctions based on religion and beliefs, local cultures and traditions, and diverse languages (see Miles, 1970; Sutama \& Asi, 2020; Karyani \& Marmanto, 2020). Based on the description above, the aim of this research is to explore specifically the kinship system of the Dayak Ribun tribe in Sanggau regency, West Kalimantan.

The object of this research was the Dayak Ribun community. They recognize patterns of control over land and forests that are passed down from generation to generation and this continues to be practiced throughout life (Mona, 2003). Likewise, the tribe initially believed in the unseen, both in the spirits of their ancestors and in rocks, mountains, and more which were considered to have power and authority in the region. At this time, they have embraced religions that have been officially accepted by the government, such as Catholicism and Protestantism.

Additionally, the Dayak Ribun Tribe is dispersed throughout Parindu regency and a small portion of Tayan Hulu, Bonti, and Kembayan. Currently, the number of ethnic Dayak Ribun is approximately 26,000 people occupying 112 villages in the five subdistricts (Arkanudin, 2005). These people have a diversity of cultures and traditions, whilst still upholding the traditions and customs of their ancestors (Mulyoutami, 2009; Niko, 2020). Eksistensi kebudayaan Dayak tidak terlepas dari kajian penelitian seperti Aini, Santoso dan Soekmadi (2016), Bakar dan Ikbal (2017, serta Peterrianus dan Mastiah (2020).

The daily life of the Dayak Ribun people depends on farming, although the field area is currently relatively small due to most already being an oil palm plantation. The products of this cultivation are only consumed for the family's and community's survival. The traditional system that is still closely related to the Ribun people shows their existence to this day. Although the reality today faced by the Dayak Ribun is the existence of oil palm plantation expansion. The expansion of the field, which began in the 1990s, has converted the Ribun's people's forest areas and fields into oil palm plantations (White \& White, 2011). This causes many problems to indigenous people, ranging from land tenure issues and tenure conflicts to massive environmental destruction (Alcorn \& Royo, 2000; Setyawan, 2010; Obidzinski et al, 2012; Haug, 2017).

Research on the kinship system in the Dayak community in Kalimantan has been carried out by Pratiwi (2017), Fitrianingrum (2018), and Efriani, Hasanah \& Bayuardi (2020) which show that there is a unique kinship system between the Dayak sub-tribes studied. For example, the research of Efriani, Hasanah, and Bayuardi (2020) shows that there is a unique kinship system due to the interaction and solidarity of the Dayak ethnic groups in Indonesia-Malaysia border, where kinship ties are more important in maintaining this ethnic harmony.

This study specifically discusses the kinship of the Dayak Ribun in Sanggau Regency. The kinship system that has been established between the Ribun people outside Sanggau Regency is intertwined with the common language, tradition, and family system that 
connects their existence. So, in this paper, I want to answer the question, how is the kinship system in the Dayak Ribun community?

\section{Methods}

The approach used in this study is an ethnographic approach. Data mining for the ethnographic data of the Ribun Dayak ethnic group was carried out around a span of 4 months in 2019 and 2020. The data needed in this study include the main data collected centered on aspects related to the ethnographic framework. Data collection techniques were carried out by (1) participant observation (participant-observation); (2) In-depth interviews and regular interviews. As a tool in conducting the interview, we used a tape recorder.

Determination of research informants was done by using the purposive sampling technique. This means that exploring interview data with informants is based on the objectives to be achieved so that the criteria for informants can be explained as follows: a) the indigenous Dayak Ribun people; b) traditional elders (tumenggung adat) of the Ribun Dayak. In this study, interview guidelines were used to collect data based on the research focus, but interview questions were further developed in the field. In conducting interviews with informants, the time spent is about 45-60 minutes for each informant.

The process of recording field data is carried out simultaneously with the process of collecting field data, so that data verification uses triangulation of data sources (informants). The process of data analysis is carried out when the researcher leaves the research field, then the process of drawing conclusions from the results of the research is carried out after the data analysis is completed. In ethnographic research, the writer cannot leave the process of reflectivity. This means that the authors carry out reflectivity on field data continuously.

This research was conducted in Parindu District, Sanggau Regency, West Kalimantan. This area was chosen as the research location with the consideration that the Dayak Ribun ethnic population in Parindu District is quite large and spread over several villages. So that the knowledge and experience of the Ribun Dayak ethnic group become important in exploration as primary data in answering the questions in this study.

The distribution of the Ribun Dayak people is in the villages of Central Peace, Sedoya, Bansu, Serosat, Kerosik, Luti, Challenge B, Sumpo, Topis, Pejugan, Layau, Mudun, Seranggas, Sungai Raya, Senara, Kerompang, Empiring, Lintang, Sembawang Bacong, Mawang, Musan, Engkalit, Sengoret, Tikas Melato, Engjika., Melabo, Modah, Amang, Empawek, Beruak, Brunai, Rakau, Keranjik, Doak, Suka Gerundi, Baharu, Tatang S and Engkayuk Village. So that the mobility of researchers also covers the entire village of the Ribun people. 


\section{Results and discussions}

\section{- The distribution of the Dayak Ribun tribe in Sanggau regency}

According to the belief of the Dayak people originating from the Kaharingan belief, Humans are descended from the seventh heaven in 4 places, namely: which is located in the upper reaches of the Kahayan and Barito rivers, which is located around Gunung Raya, In the Upper Malahui River, which is located in the area of West Kalimantan, which located in the Upper Barito River (Riwut \& Riwut, 2003). The distribution of the Dayak people encourages recognition from the district level to encourage state recognition of the existence of indigenous Dayak communities. The origin and existence of the Dayak people cannot be separated from previous research studies such as the study of Darmadi (2017),

The existence of the Ribun people in Kalimantan has been around for centuries. This can be known based on the system of traditions and culture that they have inherited which are hundreds of years old. Although the current of globalization threatens the existence of the Dayak Ribun traditions and culture, these communities still adhere to the inheritance of their ancestors (Arkanudin \& Rupita, 2021). Based on the Sanggau District Regulation Number 1 of 2017 concerning the Recognition and Protection of Indigenous Law Communities, the Dayak Ribun indigenous peoples are recognized for their existence and rights in their livelihoods and daily life.

The distribution of the Dayak Ribun tribe in Sanggau regency, West Kalimantan can be seen in the following picture:

Figure 1: Distribution of the Dayak Ribun, West Kalimantan

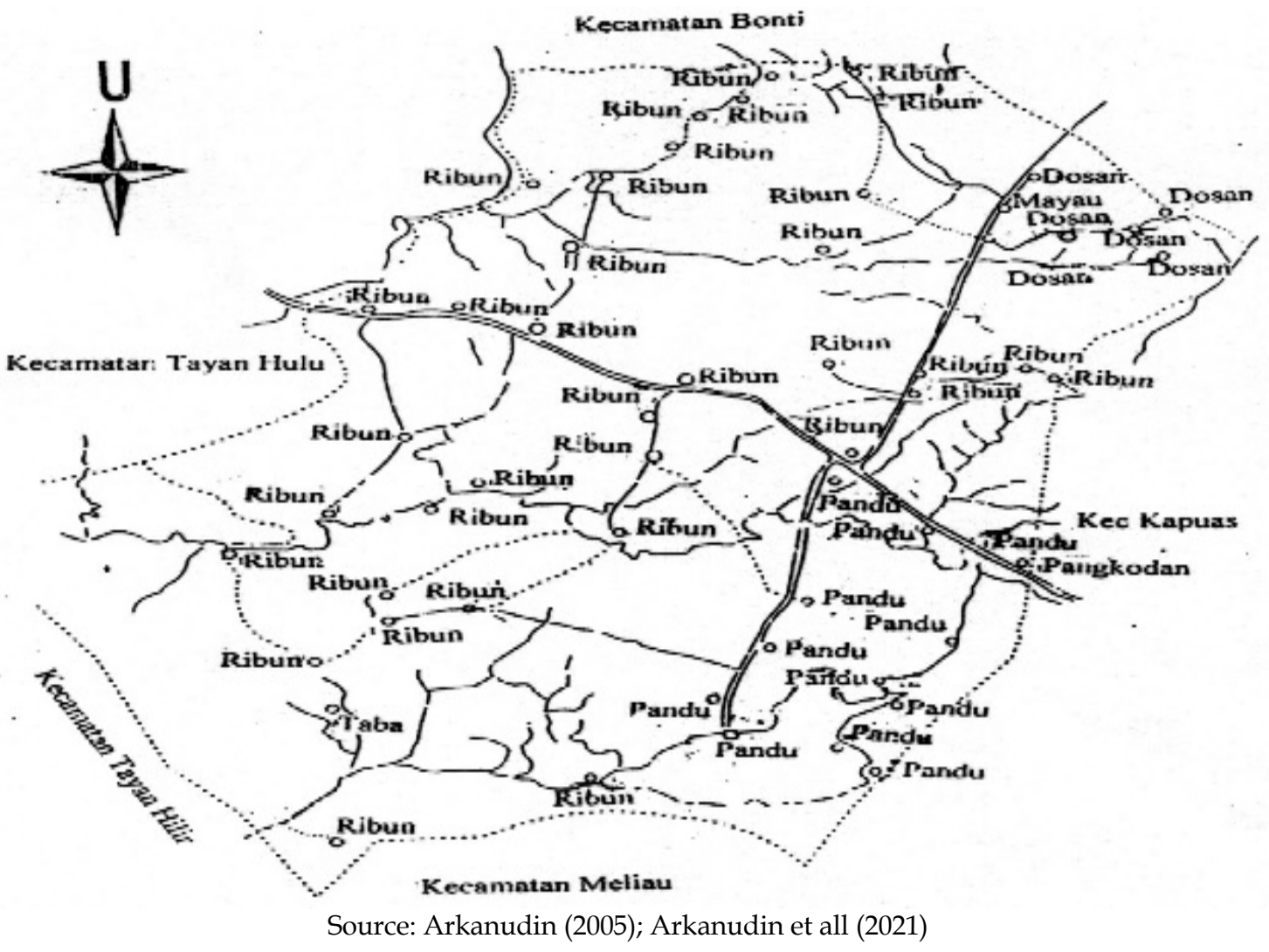




\section{- Kinship of The Dayak Ribun Tribe}

Kinship relations in the Dayak Ribun people can be divided into two groups, namely consanguineal kin, which is a group of relatives or families who have blood ties of descent from a common ancestor or the same genealogy, and affinal kin, which is a family group that is a member of a relative because one of the members married a family member of the relative.

As with other Dayak kinship systems in Kalimantan, the one that applies to the Dayak Ribun community in Parindu is bilateral, that is, relations through two family lineages, both the sides of the mother or wife and father or husband. Likewise, different experiencesincluding mixed marriages - will result in a change in the perception of a person's identity, including their ethnicity.

The principle of heredity, which is bilateral, also makes the responsibility of husband and wife equal in the family, both in the education of the child and in controlling the family economy. It is not uncommon for a mother to be involved in farming activities such as grazing, harvesting, and sap cutting. However, there are still differences in the division of labor in some cases, considering that not all work can be done by a mother.

The term kinship is derived from the Hawaiian or generation type, which is used to refer to siblings and cousins (Haviland, 1988). This is also the basis for the Dayak Ribun descendants' belief that daughters and sons receive the same treatment from their parents and relatives. Kinship of the Dayak Ribun people can be seen in the following diagram: 
Figure 2: The Dayak Ribun Kinship Diagram

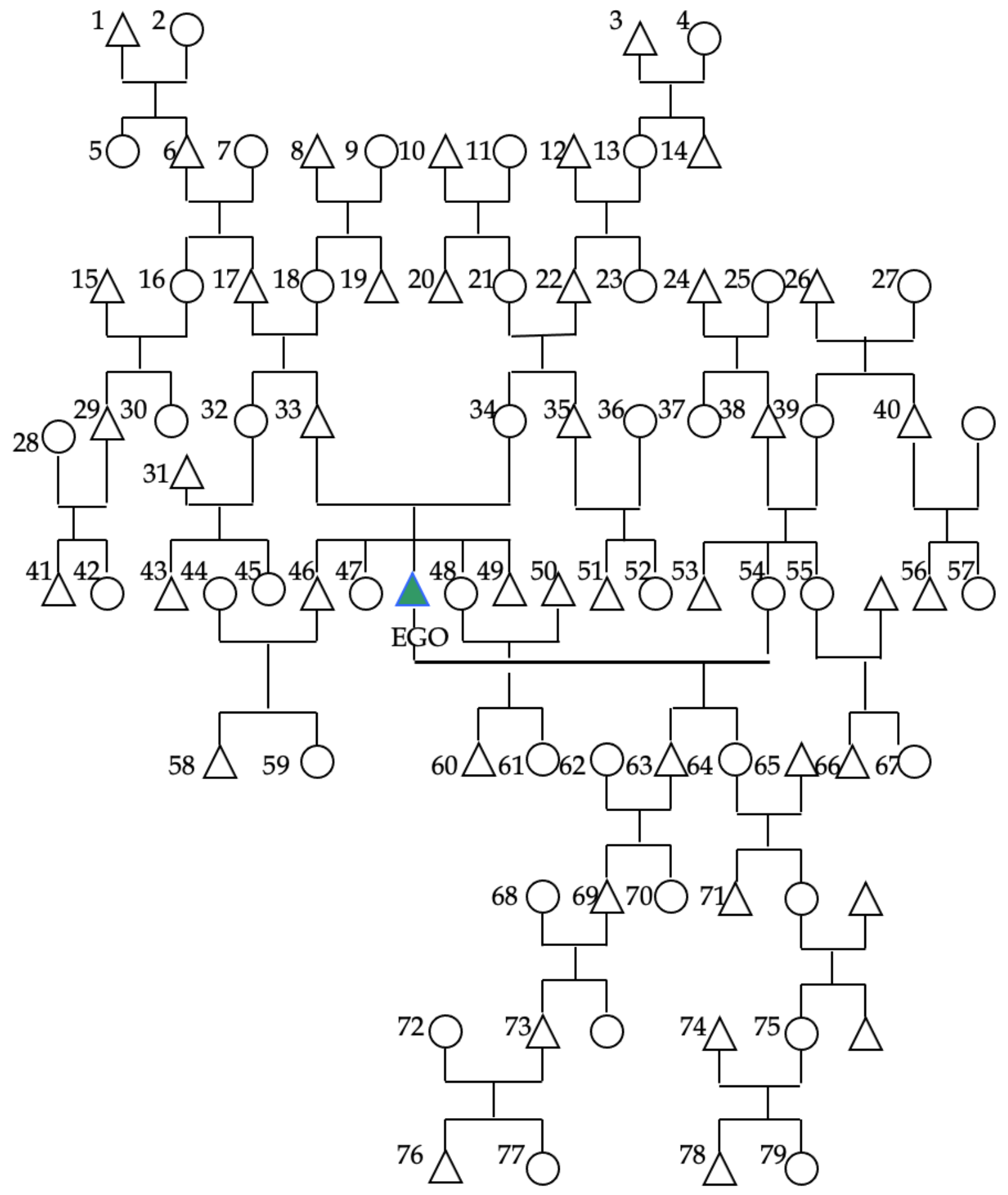

Sources: Sapardi (1991); Arkanudin (2005) 
The description of Figure 2:
Iـ = Marriage
${ }_{I}=$ young brother $/$ sister $($ ode $)$
$\bigcirc=$ Woman
$\Gamma=$ old brother $/$ sister $\left(m u^{\prime}\right) \quad \mid=$ Child (ang)
$\triangle=$ Men

Table 1: Mentions and Terms of Kinship on the Dayak Ribun People

\begin{tabular}{|c|c|c|c|}
\hline No & No in diagram & Ribun Languages & English \\
\hline 1 & $1,3,6,8,10,12,14$ & Bohou' nahi & Progenitor \\
\hline 2 & $2,4,5,7,9,11,13$ & Bohou'nayuong & Ancestor \\
\hline 3 & $15,17,19,20,22,24,26$ & Abay & Grandfather \\
\hline 4 & $16,18,21,23,25,26,27$ & $\mathrm{Ne}^{\prime}$ & Grandmother \\
\hline 5 & $28,30,32,37$ & Ma'nayuong & Aunt \\
\hline 6 & 29,31 & Ma'nahi & Uncle \\
\hline 7 & 33 & Maug/abah & Father \\
\hline 8 & 34 & $\mathrm{Ma}^{\prime}$ & Mother \\
\hline 9 & 35,40 & Bapo/wah & Uncle \\
\hline 10 & 36 & Tuo & Aunt \\
\hline 11 & 38 & Dato nahi & Father-in-law \\
\hline 12 & 39 & Dato nayuong & Mother-in-law \\
\hline 13 & $41,43,51,56$ & Ono'/Ode'nahi & Cousin \\
\hline 14 & $42,45,52,57$ & One'/Ode nayuong & Cousin \\
\hline 15 & 46 & Mu'nahi & Old Brother \\
\hline 16 & 47 & Mu'nayuong & Old Sister \\
\hline 17 & 48 & Ode'nayuong & young sister \\
\hline 18 & 49 & Ode' nahi & young brother \\
\hline 19 & 44,53 & Mu'ipah & Old Brother/sister-in-law \\
\hline 20 & 50,55 & Ode'ipah & Young Brother/sister-in-law \\
\hline 21 & 54 & Osauw & Wife \\
\hline 22 & $5859,60,51,66,67$ & Peneko & Nephew/Niece \\
\hline 23 & 63 & Ono' & Son \\
\hline 24 & 64 & One' & Daughter \\
\hline 25 & 62,65 & Ibatn & Son/daughter in law \\
\hline 26 & $68,69,70,71$ & Uco' $^{\prime}$ & Grandchild \\
\hline 27 & $72,73,74,75,76,77,7879$ & Uyuo' & great-grandchildren \\
\hline
\end{tabular}

Sources: Sapardi (1991); Arkanudin (2005)

Although the Dayak community's kinship terms are not as complex as those of Javanese people with seven generations up and down (Sapardi, 1991), they can generally get to know all members of their relatives based on the flow of their family relationships. These people always maintain good relations, which show up in mutual assistance, visits, and attendance of traditional ceremonies and family weddings.

According to Suparlan (1989), in the bilateral kinship system, personal relationships between closely related individuals determine the social and cultural distance. Therefore, the individual choice of a marriage partner appears prominent, as long as the 
person in question is not married to someone classified as a close relative, prohibited by kinship.

In the Dayak Ribun marriage system, a family member is prohibited from marrying someone still a descendant of either the father or the mother. In addition, marriage between cousins is only allowed after three cousins have been wedded. Further, if this union prohibition is done, the person who carries it out will get a "curse" or a traditional plague, and the child born is called an illegitimate child or ompang.

Subsequently, the proposal usually comes from the male side, and their parents choose someone experienced to apply. Meanwhile, the wedding reception does not have to be held at the home of the girl's parents. This decision is usually heavily influenced by the outcomes of the deliberation when the male parents first arrive when applying. Furthermore, if there is rejection from the girl's parents, it is done gently not to break her heart. However, if the proposal is accepted, the girl's parents will summon community leaders to witness the two families forming a bond. This is a strengthened custom of exchanging goods, such as rings or clothes, engaged in the Ribun's culture. They are not known for the dowry in this case.

Meanwhile, the adopted marriage principle is monogamy, which is reinforced by the teachings of the Christian religion they profess. If a polygamous marriage takes place, the husband and wife must face severe customary penalties and pay a fine for the punishment. Furthermore, the prevalent custom in this society forbids divorce. Even if this occurs, the parties who caused the divorce also face customary penalties or payment of customs fees.

According to Suparlan (1989), no one among us is not entangled and regulated in his life by various kinship and family rules. Whether we realize it or not, each of us follows the instructions in the kinship system that we have by our respective cultures. Our relatives become essential, specifically in the life cycle from the stage in the womb to death. The most crucial level is marriage and life as husband and wife.

Meanwhile, if a Dayak Ribun person marries, there is no obligation for them to live in the environment of one of their relatives. Everyone has the option to stay or leave their kinship group to join the wife's family circle. The marriage children will be raised in the same kinship environment as husband and wife. In anthropology, this custom is known as utro-local (Koentjaraningrat, 1977), but neo-local practices have recently emerged.

In the Dayak Ribun community, customs established after marriage are inseparable from the inheritance law. Children living in the same house will look after and care for their parents, and they will inherit everything. However, neo-local practices have lately begun to emerge, in which a newly married couple separates and builds a new home outside of the husband's or wife's familial environment. Also, this can be found in some Dayak families who marry outsiders such as Batak or Javanese people.

The principle of inheritance in the Dayak community does not distinguish between sons and daughters. Nonetheless, in some instances, such as the division of household responsibilities, there is still a difference in the role of both in the family. Furthermore, sons always receive a larger share of the inheritance system than daughters, particularly 
in terms of field division. On the contrary, they do not always receive greater distribution than daughters, because among the Dayak community, there is a division of inheritance, and those who stay with their parents get a larger share. Sometimes the entire inheritance of parents is given to the child who lives with the parents, because of their responsibility for the parents' old age until they die, though this does not mean that the other siblings receive nothing.

If they want to open the field from their parent's inheritance, they must first obtain permission from the family, who will then show them where they are farming. Additionally, they must acquire their brother's consent and go through a routine of dividing the rubber generated in half if they wish to cut it since they need money. Meanwhile, if a parent does not have children, their legacy will go to or be given to the person or family who cares for and looks after them until the parent dies.

\section{Conclusion}

Based on the description of the discussion of this research, it can be concluded that the kinship system of the Dayak Ribun tribe in Kalimantan is inseparable from their past traditions which are full of nomadic life. The distribution of the Ribun Dayak people, which is not only in Sanggau Regency, confirms that at the time of their ancestors, they had lived in a sedentary system. Historically, the ancestors of this ethnic group came from the West Kalimantan-Malaysia border, namely in the Nekan Entikong area, which is currently known as Tembawang Ribun. Then, the Dayak Ribun ethnic kinship system is bilateral or double descent, which is calculating kinship relations through two lineages, namely through the line of descent from the male or husband side and from the female or wife side. Then, the principle of descent from the Dayak Ribun community also recognizes the bilateral principle, which means that the responsibilities of husband and wife are equal in the family.

Based on the conclusions of this study, it can be suggested for further research, namely: research can refer to the life history of the Dayak Ribun people in looking at the general distribution in the Borneo region (Kalimantan, Sarawak, and Brunei), and include a meta-analysis to determine the specificity of the culture and traditions of the Dayak community. This is to find out the kinship roots of the Ribun Dayak people in Kalimantan can not be separated from the history of the distribution of their ancestors (grandparents) who in ancient times lived to move from one place to another, before settling down.

\section{Conflicts of Interest:}

The authors declare that there is no conflict of interest.

Acknowledgement:

Appreciation is conveyed to the Indigenous Leader and the Dayak Ribun community. We also thank the Dean of the Faculty of Social and Political Sciences, Tanjungpura University, and the reviewers of ETNOSIA: Jurnal Etnografi Indonesia. 


\section{References}

Aflanie, I., Prastowo, W., Panghiyangani, R., Yudianto, A., \& Koesbardiati, T. (2020). Genetic variation analysis and kinship relationship between Dayak Ngaju tribe and Dayak Bukit tribe through examination of core DNA of Bukit CODIS STR Locus (combine DNA index system) 13 for the purpose of Forensic Identification. Indian Journal of Forensic Medicine \& Toxicology. 14(3):1094-1097.

Aini, Y. S., Santoso, N., \& Soekmadi, R. (2016). Pengelolaan Tembawang Suku Dayak Iban di Desa Sungai Mawang, Puring Kencana, Kapuas Hulu, Kalimantan Barat. Media Konservasi, 21(2), 99-107.

Alcorn. J. B., \& Royo, A. G. (Eds). (2000). Indigenous Social Movements and Ecological Resilience: Lessons from the Dayak of Indonesia. Peoples, Forest and Reefs (PeFoR) Program Discussion Paper Series.

Arkanudin. (2005). Sebuah Penelitian Antropologi, Perubahan Sosial Masyarakat Peladang Berpindah. Pontianak: STAIN Press.

Arkanudin, Mashudi, E. Sutandar. (2021). Sacredness of Dayak Ribun Forest: Knowledge, Livelihood and Belief. Scirea Journal of Sociology. 5(5), 277-287. http://www.scirea.org/journal/Sociology

Bakar, A., \& Iqbal, I. (2017). Dinamika Kebudayaan Suku Dayak Bakumpai Di Kalimantan Tengah (Studi Tentang Akulturasi Budaya Lokal Dan Agama Islam). Prosiding; Islam and Humanities (Islam and Malay Local Wisdom), 314-329.

Coomans, M. (1987). Manusia Daya, Dahulu, Sekarang dan Masa Depan, Jakarta: Gramedia.

Darmadi, H. (2017). Dayak Asal-Usul dan Penyebarannya di Bumi Borneo (1). Sosial Horizon: Jurnal Pendidikan Sosial, 3(2), 322-340.

Efriani, E., Hasanah, H., \& Bayuardi, G. (2020). Kinship of bidayuh dayak ethnic at the border of Entikong-Indonesia and Tebedu-Malaysia. ETNOSIA: Jurnal Etnografi Indonesia, 136-149. Doi: https://doi.org/10.31947/etnosia.v5i1.8300

Fitrianingrum, E. (2018). Analisis Sistem Sapaan Kekerabatan Pada Masyarakat Dayak Kanayatn Bahasa Bangape Desa Antan Kecamatan Ngabang Kabupaten Landak (Kajian Sosiolinguitik). JURNAL KANSASI, 2(2).

Haug, M. (2017). Men, women, and environmental change in Indonesia: The gendered face of development among the Dayak Benuaq. Austrian Journal of South-East Asian Studies. 10(1), 29-46.

Haviland, W. A. (1988). Antropologi Jilid I dan II (Terjemahan), Jakarta: Penerbit Erlangga.

Karyani, L., Nababan, M. R., \& Marmanto, S. (2020). Translation Analysis on the Dayak Cultural Terms from Dayak Ngaju to Indonesian and English. Langkawi Journal of the Association for Arabic English. 6(1):41-54. Doi: http:/ / dx.doi.org/10.31332/ lkw.v6i1.1676

Kedit, P. M. (1988). Ethnicity in Multietnic Society, Dalam: Sarawak Museum Journa;, Vol $\mathrm{XL}$, Desember.

King, V. T. (1978). Revitalization Movement in Kalimantan (Indonesian Borneo), Dalam Indonesian Circle 17.

Koentjaraningrat. (1977). Beberapa Pokok-Pokok Antropologi. Jakarta: Dian Rakyat.

Lontaan. (1975). History of customary law and customs of West Kalimantan. Level I Local Government of West Kalimantan. Pontianak.

Miles, D. (1970). The Ngadju Dayaks of Central Kalimantan, with Special Reference to Upper Mentaya. Behavior Science Notes. 4, 291-319.

Mona. (2003). Onok Adak Onok Nusantara. Dalam Kumpulan Diskusi dan Presentasi KEDAI (Kelompok Diskusi Adat Indonesia). Jakarta: International Centre for Research in Agroforestry.

Mudiyono. (1990). Perubahan Sosial dan Ekologi Peladang Berpindah, Pontianak: Dalam Suara Almamater Universitas Tanjungpura, No II Tahun V Nopember 1990. 
Mulyoutami, E., Rismawan, R., \& Joshi, L. (2009). Local knowledge and management of simpukng (forest gardens) among the Dayak people in East Kalimantan, Indonesia. Forest Ecology and Management. 257:2054-2061. Doi:10.1016/j.foreco.2009.01.042

Niko, N. (2020). Gender Struggle: What Can We Learn from the Dayak Benawan Women?.Walailak Journal of Social Science.13(2):269-292. Retrieved from https://so06.tci-thaijo.org/index.php/wjss/article/view/234156

Obidzinski, K., Andriani, R., Komarudin, H., \& Andrianto, A. (2012). Environmental and social impacts of oil palm plantations and their implications for biofuel production in Indonesia. Ecology and Society, 17(1). https:// doi.org/10.5751/ES-04775-170125

Perda Kabupaten Sanggau Nomor 1 Tahun 2017 Tentang Pengakuan dan Perlindungan Masyarakat Hukum Adat. Retrieved from: https://peraturan.bpk.go.id/Home/Details/54925/perda-kab-sanggau-no-1tahun-2017

Peterianus, S., \& Mastiah, M. (2020). Eksistensi Suku Dayak Seberuang Menghadapi Tekanan Modernisasi Melalui Ritual Gawai Dayak. Bestari: Jurnal Pendidikan dan Kebudayaan, 1(2), 36-43.

Pratiwi, O. H. (2017). Analisis Kontrastif Istilah Kekerabatan Dalam Bahasa Dayak Ngaju, Banjar, Dan Dayak Maanyan. Pada International Seminar "Language Maintenance and Shift" VII, July 2017, Semarang

Riwut, N., \& Riwut, N. (2003). Maneser Panatau Tatu Hiang: Menyelami Kekayaan Leluhur. Palangkaraya: Pusakalima.

Sapardi. (1991). Pengaruh Perkebunan Inti Rakyat Terhadap Rumah Tangga Petani di Kecamatan Parindu, Tesis, Program Pascasarjana Universitas Indonesia.

Setyawan, A. D. W. I. (2010). Biodiversity conservation strategy in a native perspective; case study of shifting cultivation at the Dayaks of Kalimantan. Nusantara Bioscience, 2(2), 97-108. https://doi.org/10.13057/nusbiosci/n020208

Situmeang, S. R., Budhi, S., \& Uddin, J. (2020). Establishment of Institutions and Empowerment of Dayak Tradition (Study in Murung Raya District). Scholar International Journal of Law, Crime and Justice. 3(6):161-165. Doi: 10.36348/sijlcj.2020.v03i06.002

Suparlan, P. (1989). Sistem Kekerbatan, Keluarga, dan Peranan Pria dalam Keturunan, Dalam: berita Antropologi, Nomor 46 Tahun XIII, April - Juni

Sutama, P., Luardini, M. A., \& Asi, N. (2020). The Religious Text 'Panaturan' of the Dayak Ngaju Community. Solec International Seminar on Language, Education, and Culture. KnE Social Sciences, 247-254. DOI 10.18502/kss.v4i4.6489.

White, B., \& White, J. (2011). The gendered politics of dispossession : oil palm expansion in a Dayak Hibun community in West Kalimantan, Indonesia Global Land Grabbing. International Conference on Global Land Grabbing 6-8 April 2011.

Zulkarnaen. (2000). Hubungan Birokrasi Pemerintahan dan Lembaga Adat Dalam pembangunan, Suatu Pola Kerjasama Birokrasi Pemerintah dengan Lembaga Adat Dalam Implementasi Program Pembangunan pada Masyarakat Dayak Kalimantan Barat. Bandung: Disertasi Doktor, Program Pascasarjana UNPAD. 